\title{
Kepemimpinan Rasul Paulus Menurut Teks 1 Korintus 4:1-21 Dalam Pengembangan Yayasan Mercy Indonesia, Denpasar
}

\author{
Roberto Hutapea \\ Sekolah Tinggi Teologi Anugrah Indonesia Surabaya \\ robertdmaker@gmail.com
}

\begin{abstract}
:
This study aims to analyze the leadership concept of the Apostle Paulus 1 Corinthians 4: 1-21 in the development of the Mercy Indonesia Foundation, Denpasar. It is illustrated that the concept of democratic leadership is one of the leadership models close to the leadership of the Apostle Paul. The concept of leadership is based on text analysis of 1 Corinthians 4: 1-21. This research method uses qualitative. Data collection was carried out in literature and interviews. The results of the study concluded that the leadership concept of the Apostle Paul in the development of the Mercy Indonesia Foundation shows that Christian leaders must have a leadership concept that educates and builds, embraces, can be role models, can accompany their subordinates, and have soothing or entertaining explanations and communication.
\end{abstract}

Keywords: leadership; paul, yayasan mercy indonesia

\begin{abstract}
Abstrak:
Penelitian ini bertujuan untuk menganalisis konsep kepemimpinan Rasul Paulus 1 Korintus 4:121 dalam pengembangan yayasan Mercy Indonesia, Denpasar. Digambarkan bahwa konsep kepemimpinan demokratis menjadi salah satu model kepemimpinan yang dekat dengan kepemimpinan Rasul Paulus. Konsep kepemimpinan tersebut didasarkan pada analisa teks 1 Korintus 4:1-21. Metode penelitian ini menggunakan kualitatif. Pengumpulan data dilakukan secara literatur dan wawancara. Hasil penelitian menyimpulkan bahwa konsep kepemimpinan Rasul Paulus dalam perkembangan Yayasan Mercy Indonesia menunjukkan bahwa pemimpin Kristen mesti memiliki konsep kepemimpinan yang mendidik dan membangun, merangkul, dapat menjadi teladan, dapat mendampingi bawahannya, serta memiliki penjelasan dan komunikasi yang menyejukkan atau menghibur.
\end{abstract}

Kata Kunci: kepemimpinan; paulus; yayasan mercy indonesia

\section{Pendahuluan}

John C. Maxwell salah seorang pakar kepemimpinan, mengungkapkan bahwa kepemimpinan menjadi salah satu faktor penting bagi keberhasilan sebuah organisasi (Maxwell, 2016). Tanpa seorang pemimpin yang kompeten, sebuah organisasi akan lumpuh dan tidak dapat berkembang dengan baik. Kepemimpinan dalam organisasi pada tulisan ini dapat dibedakan menjadi dua bagian, yaitu kepemimpinan non-kristen dan kepemimpinan Kristen. Kepemimpinan non-kristen berkaitan dengan kepemimpinan yang terjadi di luar organisasi kekristenan atau kepemimpinan secara umum. Sementara kepemimpinan Kristen berkaitan dengan kepemimpinan yang terjadi di dalam organisasi Kristen. 
Konsep kepemimpinan Kristen tentu berbeda dengan kepemimpinan secara umum. Perbedaan konsep tersebut dipertegas oleh Derek Tiball yang dikutip oleh Yakob Tomatala. Ia menulis bahwa kepemimpinan Kristen dimaksudkan untuk menjadi berbeda dari bentuk-bentuk kepemimpinan lainnya karena pemimpin Kristen dipanggil untuk menjadi hamba (Tomatala, 2008). Konsep kepemimpinan ini tentu sangat berbeda dengan konsep kepemimpinan secara umum yang mementingkan aspek kekuasaan yang tinggi dalam memimpin.

Perkembangan teknologi informasi pada masa kini, dalam sebuah organisasi Kristen dibutuhkan pemimpin yang memiliki karakter yang kuat dan kompetensi yang kuat pula (Kouzes \& Posner, 2004). Artinya, seorang pemimpin perlu memiliki kemampuan dalam memahami dan menggunakan teknologi informasi. Memiliki kemampuan teknologi dan memiliki karakter yang kuat merupakan bagian dari pemimpin yang kuat. Untuk menjadi seorang pemimpin yang kuat dan berkarekter tentu tidaklah mudah. Artinya, organisasi Kristen masih menghadapi persoalan yang berkaitan dengan kepemimpinan yang kuat dan berkarakter tersebut. John Stott mengungkapkan bahwa di gereja masih mengalami pergumulan tentang pemimpin yang berkualitas. Gereja masih kekurangan pemimpin berkualitas seperti pribadi Kristus (Stott, 2005). Permasalahan yang berkaitan dengan kepemimpinan Kristen ini, menunjukkan bahwa organisasi Kristen masih mengalami pergumulan dalam hal kepemimpinan. Dengan kata lain, untuk menjadi seorang pemimpin dalam suatu organisasi tidaklah mudah, butuh proses dan perjuangan.

Pandangan tentang pemimpin di atas, menunjukkan bahwa untuk menjadi seorang pemimpin dalam organisasi Kristen tidak dapat lepas dari yang namanya proses. Apa lagi yang menjadi prinsip penting dari seorang pemimpin Kristen adalah karakter dan keteladanan. Hal ini tentu sangat erat kaitannya dengan nilai-nilai kebenaran kekristenan itu sendiri yang berfokus pada Kristus. Tomatala dalam tulisannya tentang kepemimpinan Yesus Kristus yang par-ekselens mengemukakan prinsip inti kepemimpinan Kristus. Prinsip inti kepemimpinan Kristus tersebut adalah memimpin dengan hati, memimpin berlandaskan kasih, dan memimpin dengan kekuatan kebenaran kebaikan (Tomatala, 2008).

Berkaitan dengan pemimpin Kristen tersebut, J. Robert Clinton dalam Y. Tomatala menekankan prinsip penting lainnya. Clinton mengatakan bahwa pemimpin Kristen adalah seseorang yang telah dipanggil Allah sebagai pemimpin yang ditandai dengan adanya kapasitas memimpin, tanggung jawab untuk memimpin kelompok umat Allah (gereja), dan mencapai tujuan-Nya melalui kelompok umat Allah tersebut (Tomatala, 2005). Pemimpin Kristen dalam proses menjadi pemimpin yang memiliki prinsip tersebut, tentu membutuhkan figur kepemimpinan. Pemimpin Kristen mengacu pada figur dan berkarakter seperti Kristus tentu menjadi harapan setiap pemimpin dalam organisasi Kristen. Dalam organisasi Kristen, figur kepemimpinan dapat dipelajari dari pribadi Kristus, dan dapat juga dipelajari dari tokoh-tokoh Alkitab, misalnya tokoh Rasul Paulus. Rasul Paulus adalah seorang pemimpin besar dari gereja Tuhan di abad pertama. Dalam kitab 1 Korintus 11:1 berbunyi, "Jadilah pengikutku, sama seperti aku juga menjadi 
pengikut Kristus." Rasul Paulus berhasil memultiplikasikan kepemimpinannya dengan mencetak pemimpin-pemimpin baru yang berkarakter. Ia berhasil mendidik Timotius menjadi pemimpin dan gembala yang andal. Timotius pun kemudian menghasilkan pemimpin-pemimpin baru di dalam gereja yang digembalakannya.

Belajar dari kepemimpinan Rasul Paulus, proses untuk menjadi pemimpin gereja mula-mula tidaklah mudah. Banyak tantangan yang dihadapi oleh Rasul Paulus. Salah satunya dalam konteks 1 Korintus 4:1-21. Dalam konteks ini, Rasul Paulus menghadapi berbagai permasalahan dan pertentangan yang datang dari jemaat Korintus. Permasalahan yang paling mengemuka adalah perselisihan antara jemaat berkaitan ketokohan dan figur pemimpin rohani. Ada tiga tokoh kuat yang saling dipertentangkan oleh jemaat Korintus pada saat itu, yaitu munculnya nama Paulus, Apolos, dan Kefas. Pertentangan ini mulai muncul pada pasal 1:12 lanjut pasal 3:4-6, dan ayat 22. Sebagai pendiri jemaat, tentu Rasul Paulus memiliki beban berat, dimana beban tersebut ialah menyelamatkan dan menghindari terjadinya perpecahan dalam jemaat. Dalam kondisi ini, Rasul Paulus butuh strategi dan upaya dalam menghadapi persoalan tersebut. Penelitian ini akan mencoba membedah konsep dan strategi kepemimpinan Rasul Paulus dalam menghadapi dan mengatasi permasalahan yang terjadi seperti yang tertuang dalam teks 1 Korintus 4:1-21. Dan mengimplikasikannya dalam kepemimpinan di Yayasan Mercy Indonesia, Denpasar.

Konsep kepemimpinan Rasul Paulus yang muncul dalam mengatasi permasalahan jemaat Korintus di atas, akan menjadi dasar dalam penelitian ini. Terutama terkait implikasi kepemimpinan Rasul Paulus pada Yayasan Mercy Indonesia, Denpasar. Peneliti akan mengkaji bagaimana konsep kepemimpinan Rasul Paulus terimplikasi dalam kepemimpinan di Yayasan ini. Berkaitan dengan Yayasan Mercy Indonesia ini, memiliki sepuluh (10) cabang Lembaga Kesejahteraan Sosial Anak (LKSA) yang tersebar di berbagai provinsi di Indonesia. Kesepuluh cabang LKSA tersebut adalah sebagai berikut: LKSA Mercy Denpasar, LKSA Mercy Kaliwesi Jawa Tengah, LKSA Mercy Teluk Dalam Nias, LKSA Mercy Medan, LKSA Mercy Singkawang, LKSA Mercy Waikabubak Sumba Barat, LKSA Mercy Rote, LKSA Mercy Soe, LKSA Mercy Atambua, dan LKSA Mercy Sorong (Wiratno, 2019).

Yayasan Mercy Indonesia dan atau LKSA ini dipimpin oleh Paulus Wiratno. Dalam memimpin lembaga ini tentu tidaklah mudah, apalagi cabang lembaga ini tersebar di berbagai provinsi yang ada di Indonesia. Dalam aspek organisasi sudah tentu membutuhkan energi dan tenaga yang tidak sedikit. Banyak persoalan dan tantangan yang dihadapi, baik yang berkaitan dengan pengembangan sarana prasarana, manajemen, sumber daya manusia, pendanaan, kerja sama, dan lain sebagainya. Untuk itu, melalui penelitian ini, peneliti akan menggali lebih dalam konsep kepemimpinan yang digunakan dalam lembaga ini. Peneliti juga akan melihat gambaran bagaimana kepemimpinan di Yayasan Mercy Indonesia, Denpasar dan kaitannya dengan pengaplikasian konsep kepemimpinan Rasul Paulus dalam Teks 1 Korintus 4:1-21. Peneliti akan menggali kepemimpinan Yayasan Mercy Indonesia dalam lima tahun terahir. Ada pun rumusan masalah dalam penelitian ini adalah Bagaimana konsep kepemimpinan Rasul Paulus 
menurut Teks 1 Korintus 4:1-21 dan implikasinya pada pengembangan Yayasan Mercy Indonesia, Denpasar? Penelitian ini akan mengkaji konsep kepemimpinan dalam indikator: mendidik dan membangun, merangkul, menjadi teladan, mendampingi, serta memberikan penjelasan yang menyejukkan. Pembahasan indikator kepemimpinan ini menjadi kelebihan dari penelitian ini dibanding dengan penelitian-penelitian lainnya yang pernah ada. Dengan demikian, tujuan dari penelitian ini adalah untuk mengetahui konsep kepemimpinan Rasul Paulus menurut Teks 1 Korintus 4:1-21 dan implikasinya pada pengembangan Yayasan Mercy Indonesia, Denpasar.

\section{Metode}

Metode penelitian adalah suatu cara yang digunakan untuk mencapai sasaran. Adapun metode yang peneliti pakai adalah metode deskriptif kualitatif, yang dilengkapi dengan studi kepustakaan. Ada pun yang menjadi subyek dalam penelitian ini adalah pendiri atau pimpinan Yayasan Mercy Indonesia. Batasan waktu kepemimpinan yang dimaksud adalah lima tahun terakhir. Pendiri atau pimpinan utama Yayasan Mercy Indonesia adalah 1 (satu) orang. Instrumen penelitian ini mencakup indikator dari kepemimpinan demokratis yang dikaitkan dengan teks 1 Korintus 4:1-21. Indikatornya meluputi: mendidik dan membangun, merangkul, menjadi teladan, mendampingi, serta memberikan penjelasan yang menyejukkan. Instrumen penelitian ini menjadi dasar untuk mengumpulkan data penelitian dengan teknik wawancara. Teknik wawancara yang digunakan adalah teknik wawancara mendalam. Wawancara mendalam ialah teknik pengumpulan data dengan pertanyaan-pertanyaan yang dapat berkembang sesuai data yang dibutuhkan (Sugiyono, 2016).

Teknik analisis data dimaksudkan untuk mengolah data agar hasil penelitian dipertanggungjawabkan dan dipercaya kebenarannya. Menurut Miles dan Huberman dalam Djama'an Satori, mengemukakan bahwa aktivitas dalam analisis data dilakukan secara interaktif dan berlangsung secara terus-menerus sampai tuntas. Aktivitas dalam analisis data tersebut, yaitu data reduction, data display, dan conclusion drawing /verification (Satori, 2014).

\section{Hasil dan Pembahasan}

\section{Hasil Penelitian}

\section{Konsep Kepemimpinan Secara Umum}

Pengertian dari kepemimpinan dapat diungkapkan oleh beberapa ahli. Secara etimologi dalam Kamus Besar Bahasa Indonesia (KBBI), kata kepemimpinan berasal dari kata dasar pimpin, yang artinya dibimbing, dituntun. Kepemimpinan artinya perihal pemimpin; cara memimpin (KBBI, 2009). Sementara itu, menurut Handoko, kepemimpinan adalah kemampuan yang dipunyai seseorang untuk mempengaruhi orang-orang lain agar bekerja mencapai tujuan dan sasaran (Handoko, 2001). Pendapat ahli lain, Ningrat menjelaskan kepemimpinan ialah suatu proses dimana pimpinan digambarkan akan memberi perintah atau pengarahan, bimbingan atau mempengaruhi pekerjaan orang lain dalam memilih dan mencapai tujuan yang telah ditetapkan (Ningrat, 
2003). Selanjutnya, Pariata Westra mengungkapkan, kepemimpinan adalah proses pengaruh-mempengaruhi antarpribadi dalam suatu situasi tertentu, melalui aktivitas komunikasi yang terarah untuk mencapai suatu tujuan-tujuan tertentu (Westra, 2002). Dari beberapa pendapat para ahli tersebut, pengertian kepemimpinan dapat disimpulkan. Kepemimpinan adalah suatu proses dalam memimpin dan mempengaruhi orang lain untuk mencapai tujuan tertentu.

Kepemimpinan secara umum memiliki sifat. Adapun sifat kepemimpinan menurut Miftah Thoha adalah sebagai berikut (Thoha, 2005): pertama, kecerdasan. Kepemimpinan mempunyai tingkat kecerdasan yang lebih tinggi dibandingkan dengan yang dipimpin. Kedua, kedewasaan dan keleluasaan hubungan sosial. Kepemimpinan cenderung menjadi matang dan mempunyai emosi yang stabil, serta mempunyai perhatian yang luas terhadap aktifitas-aktifitas sosial. Ketiga, motivasi diri dan dorongan prestasi. Para pemimpin secara relatif mempunyai dorongan motivasi yang kuat untuk berprestasi. Mereka berusaha mendapatkan penghargaan yang intrinsik dibandingkan dari yang ekstrinsik. Keempat, sikap-sikap hubungan manusia. Pemimpin-pemimpin yang berhasil mau mengakui harga diri dan kehormatan para pengikutnya dan mampu berpihak padanya.

Kemudian, memahami gaya kepemimpinan juga menjadi bagian yang penting untuk dilakukan. Ningrat membagi gaya atau tipe dari kepemimpinan menjadi tiga bagian (Ningrat, 2003). Adapun ketiga bagian dari gaya kepemimpinan itu yaitu: pertama, pemimpin otokratis. Pemimpin yang bersifat otokratis memperlihatkan ciri-ciri sebagai berikut: memberikan perintah-perintah yang selalu diikuti, menentukan kebijaksanaan karyawan tanpa sepengetahuan mereka. Tidak memberikan penjelasan secara terperinci tentang rencana yang akan datang, tetapi sekedar mengatakan kepada anggotanya tentang langkah-langkah yang mereka lakukan dengan segera dijalankan. Memberikan pujian kepada meraka yang selalu menurut kehendaknya dan melontarkan kritik kepada mereka yang tidak mengikuti kehendaknya. Selalu jauh dengan anggota sepanjang masa. Kedua, pemimpin demokratis.

Pemimpin demokratis hanya memberikan perintah setelah mengadakan musyawarah dahulu dengan anggotanya dan mengetahui bahwa kebijaksanaannya hanya dapat dilakukan setalah dibicarakan dan diterima oleh anggotanya. Pemimpin tidak akan meminta anggotanya mengerjakan sesuatu tanpa terlebih dahulu memberitahukan rencana yang akan mereka lakukan. Baik atau buruk, benar atau salah adalah persoalan anggotanya dimana masing-masing ikut serta bertanggung jawab sebagai anggotanya. Ketiga, pemimpin liberal. Pemimpin liberal yaitu kebebasan tanpa pengendalian. Pemimpin tidak memimpin atau mengendalikan bawahan sepenuhnya dan tidak pernah ikut serta dengan bawahannya.

Salah satu tipe kepemimpinan yaitu kepemimpinan demokratis. Adapun karakteristik dari tipe atau gaya kepemimpinan demokratis adalah sebagai berikut (Siagian, 2005): pertama, kemampuan mempertahankan organisasi sebagai suatu totalitas dengan menempatkan semua satuan organisasi pada proporsi yang tepat dengan tergantung pada sasaran yang ingin dicapai oleh organisasi yang bersangkutan pada 
kurun waktu tertentu. Kedua, mempunyai persepsi yang holistik mengenai organisasi yang dipimpinnya. Ketiga, menempatkan organisasi sebagai keseluruhan diatas kepentingan diri sendiri atau kepentingan kelompok tertentu dalam organisasi. Keempat, mengakui dan menjunjung tinggi harkat dan martabat para bawahannya sebagai makhluk sosial dan sebagai individu yang mempunyai jati diri yang khas. Kelima, sejauh mungkin memberikan kesempatan kepada para bawahannya berperan serta dalam prosas pengambilan keputusan terutama yang menyangkut tugas para bawahan yang bersangkutan. Keenam, terbuka terhadap ide, pandangan dan sasaran orang lain termasuk bawahannya. Ketujuh, memiliki perilaku keteladanan yang menjadi panutan kepada para bawahannya. Kedelapan, bersifat rasional dan objektif dalam menghadapi bawahan terutama dalam menilai perilaku dan prestasi kerja karyawan. Kesembilan, selalu berusaha menumbuhkan dan memelihara iklim kerja yang kondusif dan kreatif bawahan.

Selanjutnya, dalam konsep kepemimpinan Kristen, ada beberapa aspek penting yang menentukan keberhasilan seorang pemimpin. Aspek-aspek penting ini berkaitan dengan kualifikasi dari seorang pemimpin. Kualifikasi tersebut diantaranya: kualifikasi kepribadian, kualifikasi kehidupan di tengah keluarga, kualifikasi kehidupan di tengah masyarakat, serta kualifikasi kehidupan rohani dan pelayanan (Ohodo \& Marini, 2021). Senada dengan kualifikasi tersebut, Iksantoro (2019) mengungkapkan kualifikasi seorang pemimpin Kristen yaitu: kualifikasi keluarga, kualifikasi kepribadian, kualifikasi sosial, kualifikasi spiritual, dan kualifikasi profesional. Kualifikasi kepemimpinan ini penting untuk dimiliki oleh seorang pemimpin dalam sebuah organisasi.

\section{Konsep Kepemimpinan Paulus Menurut Teks 1 Korintus 4:1-21}

Konsep kepemimpinan Rasul Paulus dalam Teks 1 Korintus, setidaknya perlu memahami tujuan penulisan. Tujuan penulisan 1 Korintus ini dapat dilihat dari pemikiran Paulus itu sendiri. Adapun tujuan penulisan dari Teks 1 Korintus tersebut di antaranya (Marxsen, 2009): pertama, untuk membetulkan masalah yang serius dalam jemaat di Korintus yang telah diberitahukan kepadanya. Hal-hal ini meliputi pelanggaran yang dianggap remeh oleh orang Korintus, tetapi dianggap oleh Paulus sebagai dosa serius. Kedua, untuk memberikan bimbingan dan instruksi atas berbagai pertanyaan yang telah ditulis oleh orang Korintus. Hal-hal ini meliputi soal doktrin dan juga perilaku dan kemurnian sebagai perorangan dan sebagai jemaat.

Selanjutnya berdasarkan tafsiran dari Teks 1 Korintus 4:1-21. William Barclay dalam tafsirannya menjelaskan beberapa poin dari teks 1 Korintus 4 (Barclay, 2006). Berikut ini penjelasan dari tafsiran teks tersebut. Jika memperhatikan pasal 4 dengan seksama, maka dapat menemukan satu poin penting: jemaat Korintus ternyata memiliki sikap antipati terhadap Paulus. Ketika mereka memilih Apolos atau Kefas, hal itu tidak semata-mata didasarkan pada kelebihan dari dua tokoh tersebut. Pilihan ini didasarkan pada ketidaksenangan mereka terhadap Paulus. Mereka sedang menghakimi Paulus (4:3). Mereka melupakan semua jasa Paulus yang telah berjuang begitu keras di kota Korintus (4:7-13; bdk. Kis 18). Mereka meragukan kerasulan Paulus (9:1-3). 
Dalam responnya terhadap serangan ini, Paulus berusaha memberikan pembelaan yang sifatnya umum maupun khusus. Pembelaan yang umum dapat kita lihat dari penggunaan kata ganti orang pertama jamak "kami" di pasal 4 (ay. 1, 6, 8-13), sedangkan pembelaan khusus terlihat dari kata ganti "aku" (ay. 3-4, 14-16). Dia ingin mengajarkan prinsip umum yang dapat diterapkan pada semua pemimpin rohani, tetapi dia juga berusaha menjelaskan keunikan relasinya dengan jemaat Korintus dibandingkan dengan rasu-rasul lain (ay. 14-16). Inti pembahasan di pasal 4:1-5 adalah posisi para pemimpin sebagai hamba Kristus (ay. 1). Sebagai hamba Kristus, mereka nanti akan dihakimi oleh Tuhan sendiri (ay. 5). Dua hal ini, posisi sebagai hamba dan penghakiman terakhir, sebelumnya sudah dibahas secara terpisah oleh Paulus: pemimpin sebagai pelayan ada di pasal 3:5-9, sedangkan penghakiman terhadap para pemimpin ada di pasal 3:10-17. Dengan demikian Paulus sebenarnya hanya menerapkan prinsip tersebut dalam kasus jemaat Korintus yang menghakimi dia.

Paulus merasa perlu menegaskan posisinya sebagai hamba Kristus (4:1) untuk menghindari kesalahpahaman dari jemaat Korintus. Para rasul memang milik jemaat (3:21-22), tetapi hal itu tidak berarti bahwa mereka dapat diperlakukan semau jemaat. Mereka memang melayani kebutuhan keselamatan jemaat (lihat pembahasan di pasal 3:21-23), namun mereka tetap adalah hamba Kristus, bukan hamba mereka. Sebagai hamba Kristus, para rasul bertanggung-jawab kepada Kristus yang menjadi tuan mereka. Kristuslah yang berhak menghakimi mereka, bukan jemaat Korintus.

Berikut ini akan dibahas beberapa konsep atau nilai yang terkait dengan kepemimpinan Rasul Paulus ketika memimpin dan mengembalakan jemaat Korintus. Berdasarkan tafsiran teks 1 Korintus, berikut ini beberapa nilai dari kepemimpinan Rasul Paulus. pertama, pemimpin yang mendidik dan membangun. Teks 1 Korintus 4:14, mengungkapkan kepemimpinan Rasul Paulus yg penuh kasih, tidak akan membiarkan orang lain berjalan menuju pada celaka. Tidak juga akan pernah mempermalukan anakanak-Nya. Kasih yang mendidik dan membangun. Selama berada di Korintus Paulus membawa orang-orang disana pada Kristus. Bahkan setelah berpisah pun Paulus tetap menghadirkan kasih melalui suratnya. Kedua, pemimpin yang merangkul. Teks 1 Korintus 4:15, mengungkapkan nilai kepemimpinan yang ditunjukkan Paulus bukan hanya sekedar mendidik. Pendidik belum tentu berperan sebagai bapak namun seorang bapak tentunya juga harus mendidik. Paulus tidak hanya memberikan teguran tetapi juga membawa orang pada karya keselamatan melalui Injil yang diberitakannya. Injil adalah kekuatan Allah Roma 1:16. Menyampaikan berita Injil sesungguhnya adalah memberikan kekuatan supranatural pada orang tersebut. Menyampaikan berita Injil adalah harta terbesar yang dapat dibagikan umat Tuhan. Hal tersebut hanya dapat dilakukan dengan bimbingan dan rangkulan Paulus kepada jemaat.

Ketiga, pemimpin yang menjadi teladan. Teks 1 Korintus 4:16, mengungkapkan Paulus memberikan dirinya sebagai teladan untuk diikuti oleh jemaat Korintus yang adalah anak-anak rohaninya. Menjadi teladan bukanlah hal yang mudah karena berarti harus selalu belajar untuk menguasai diri dalam segala hal 2 Tim4:5. Demikian halnya keteladanan kepemimpinan yang ditunjukkan oleh Paulus kepada jemaat Korintus. 
Keempat, pemimpin yang mendampingi. Dalam Teks 1 Korintus 4:17, menggambarkan bahwa sekalipun sudah terpisah jarak yang jauh antara Paulus dan jemaat Korintus, namun Paulus tetap mendampingi jemaat Korintus dalam pergumulan yang mereka hadapi. Itulah nilai kepemimpinan yang penuh kasih yang dihadirkan oleh Paulus bagi jemaat Korintus. Seharusnya Paulus dapat melepaskan tanggung jawab itu seusai pelayanannya di Korintus, namun Paulus lebih memilih untuk tetap memperhatikan dan mendampingi jemaat oleh karena kasih. Kelima, pemimpin yang memberikan penjelasan yang menyejukkan. Teks 1 Korintus 4:18-21, menunjukkan bahwa pada saat Paulus terhalang secara fisik untuk mengunjungi jemaat Korintus. Namun di tengah keterbatasan itu, Paulus memberikan penjelasan yang menghiburkan dan menyejukkan saat jemaat Korintus mengalami permasalahan dan perbantahan diantara jemaat.

Konsep atau nilai-nilai kepemimpinan yang ditunjukkan oleh Rasul Paulus kepada jemaat Korintus, menunjukkan bahwa gaya kepemimpinan Rasul Paulus mendekati gaya kepemimpinan demokratis. Dimana gaya kepemimpinan demokratis seperti yang dijelaskan sebelumnya bahwa kepemimpinan demokratis perlakukannya bersifat kerakyatan atau persaudaraan, mengharap kerja sama dengan anak buahnya yang tidak dipandang sebagai alat, tetapi dianggap sebagai manusia (Sunindhia \& Widiyanti, 2001). Rasul Paulus pun demikian, kepemimpinan yang memperlakukan jemaat sebagai jemaat milik Tuhan.

\section{Pembahasan}

Pengolahan data hasil penelitian ini berasal dari pertanyaan-pertanyaan wawancara yang diajukan kepada informan. Dimana informan tersebut adalah pendiri dan pimpinan Yayasan Mercy Indonesia. Pertanyaan-pertanyaan yang diajukan terdiri atas 13 (tigabelas) pertanyaan yang merupakan indikator dari gaya kepemimpinan demokratis (Sunindhia \& Widiyanti, 2001). Dimana menurut tafsiran teks 1 Korintus 4:121, konsep kepemimpinan yang dimiliki oleh Rasul Paulus dekat dengan gaya kepemimpinan demokratis. Hasil olah data penelitian tersebut, dapat diambil beberapa pokok pembahasan terkait dengan pertanyaan-pertanyaan wawancara. Pokok-pokok pembahasan ini menyangkut nilai atau konsep kepemimpinan demokratis yang dimiliki oleh Rasul Paulus dan implikasinya pada kepemimpinan di Yayasan Mercy Indonesia. Adapun konsep kepemimpinan tersebut adalah sebagai berikut.

\section{Mendidik dan Membangun}

Berdasarkan pertanyaan yang diajukan kepada informan dalam wawancara dengan pimpinan Yayasan Mercy Indonesia, menunjukkan bahwa pimpinan mengedepankan konsep atau nilai mendidik dan membangun dalam yayasan. Hal ini nampak dari sikap pimpinan yayasan dalam membangun komunikasi dengan bawahan atau karyawan di yayasan. Pimpinan yayasan mengedepankan nilai kekeluargaan dalam menegur, membimbing, dan mengarahkan karyawan di yayasan. Nilai ini pun dilakukan oleh Rasul Paulus terhadap jemaat Korintus yang dipimpinnya. Paulus selalu memberikan 
didikan yang baik kepada jemaat Korintus atas permasalahan yang dihadapi. Konsep ini dapat dilihat dari teks 1 Korintus 4:14.

Selain itu, perkembangan Yayasan Mercy Indonesia di dalam pekerjaan, selaku pimpinan yayasan selalu memberikan tugas dan tanggung jawab kepada karyawan dengan mendelegasikan tugas secara tepat pada karyawan. Hal ini menjadi poin penting dalam kemajuan dan perkembangan di Yayasan Mercy Indonesia. Berkaitan dengan pendelegasian tugas ini, tentu ada tujuan dan manfaatnya bagi iklim pekerjaan di yayasan. Petrus Oktavianus menjelaskan tujuan dari pendelegasian. Adapun tujuan dari pendelegasian adalah (Oktavianus, 2003): pertama, untuk mendapatkan orang-orang lain yang cakap untuk melakukan tugas-tugas, baik waktu darurat maupun waktu-waktu yang akan datang. Kedua, dengan pendelegasian banyak orang dilibatkan dalam tugas kepemimpinan sehingga mencegah kegagalan yang mungkin timbul. Ketiga, pekerjaan dapat dilaksanakan lebih banyak dan lebih baik.

\section{Merangkul}

Berdasarkan data hasil penelitian yang diperoleh dari informan pimpinan Yayasan Mercy Indonesia, menunjukkan bahwa konsep kepemimpinan Rasul Paulus, yaitu konsep merangkul sudah ditunjukkan oleh pimpinan Yayasan Mercy Indonesia. Kondisi ini dapat dilihat dari jawaban informan yang berkaitan dengan pemberian bimbingan, nasehat, teguran, dan dorongan terhadap karyawan yang menghadapi masalah dan pelanggaran. Konsep merangkul ini didasarkan pada nilai kasih dan kekeluargaan yang sudah melekat dalam setiap orang yang ada di Yayasan Mercy Indonesia.

Konsep merangkul yang ditunjukkan oleh pimpinan Yayasan Mercy Indonesia ini, tentu sejalan dengan pendapat Siagian (2005) yang mengungkapkan nilai-nilai dari gaya kepemimpinan demoratis. Salah satunya adalah mengakui dan menjunjung tinggi harkat dan martabat para bawahan sebagai makhluk sosial dan sebagai individu yang mempunyai jati diri yang khas. Demikian juga ditegaskan oleh Tomatala (2008). Ia menegaskan bahwa dalam memimpin perlu sikap merangkul yang memberikan dorongan dan motivasi bagi bawahan. Hal ini terkait dengan salah satu fungsi dari kepemimpinan yang disebutkan oleh Tomatala. Fungsi tersebut adalah fungsi kegiatan pemimpin yang mencakup: membuat keputusan, membina komunikasi terpadu-harmonis, memberi motivasi bagi dan dalam tugas, memilih orang yang tepat untuk tugas yang tepat pula, serta mengembangkan setiap orang dalam dan untuk tugas yang dilaksanakan. Berkaitan dengan penegasan prinsip di atas, pimpinan Yayasan Mercy Indonesia telah memperlakukan karyawan yayasan dengan baik, yaitu dengan merangkul karyawan atas permasalahan hidup yang dialami. Hal ini sejalan dengan upaya Rasul Paulus dalam merangkul jemaat Korintus yang sedang mengalami permasalahan dalam jemaat, seperti yang tertera dalam teks 1 Korintus 4:15.

\section{Menjadi Teladan}

Hasil pengolahan data atas wawancara dengan informan pimpinan Yayasan Mercy Indonesia menunjukkan bahwa konsep keteladanan menjadi bagian penting dalam 
kepemimpinan di yayasan. Hal ini dapat dilihat dari jawaban informan terkait menjadi teladan bagi karyawan di yayasan. Kondisi ini sejalan dengan gaya kepemimpinan demokratis yang mengedepankan keteladanan dalam memimpin. Konsep keteladanan ini juga diekspresikan oleh Rasul Paulus kepada jemaat Korintus. Dalam teks 1 Korintus 4:16, Paulus memberikan dirinya sebagai teladan untuk diikuti oleh jemaat Korintus yang adalah anak-anak rohaninya. Berkaitan dengan konsep kepemimpinan untuk menjadi teladan ini juga ditegskan oleh Stott (2005). Ia menegaskan bahwa untuk menjadi pemimpin Kristen mesti memiliki karakter dan integritas. Artinya, pemimpin Kristen harus dapat menjadi teladan dalam hidupnya. Dengan karakter dan integritas, pemimpin Kristen dapat mengembangkan yayasan atau organisasi yang dipimpin.

\section{Mendampingi}

Hasil pengolahan data dari informan sebagai hasil wawancara menunjukkan bahwa konsep mendampingi menjadi bagian dalam kepemimpinan di Yayasan Mercy Indonesia. Hal ini nampak dari upaya pimpinan yayasan yang selalu membangun komunikasi dalam merencakana, memutuskan, dan melaksanakan suatu program pekerjaan. Pelaksanaan pekerjaan tersebut selalu dipantau atau didampingi oleh pimpinan yayasan, sehingga pekerjaan tersebut dapat dilaksanakan dengan baik. Konsep mendampingi ini pun ditunjukkan oleh Rasul Paulus kepada jemaat Korintus. Dalam teks 1 Korintus 4:17, menggambarkan bahwa sekalipun sudah terpisah jarak yang jauh antara Paulus dan jemaat Korintus, namun Paulus tetap mendampingi jemaat Korintus dalam pergumulan yang mereka hadapi.

Konsep kepemimpinan demokratis dimana pemimpin mesti dapat mendampingi bawahannya dalam suatu program pekerjaan ditegaskan oleh Arifin (2012). Ia mengutip pendapat Stephen R. Coney tentang karakteristik dari seorang pemimpin. Dimana salah satu karakteristik dari seorang pemimpin adalah dapat memberikan energi positif buat orang lain. Artinya, seorang pemimpin dapat memberikan dorongan, motivasi, dan pendampingan yang baik kepada bawahannya di dalam melaksanakan suatu pekerjaan. Sehingga keberhasilan dalam suatu pekerjaan menjadi keberhasilan dalam organisasi yang dipimpin. Demikian halnya dengan Yayasan Mercy Indonesia. Konsep pemimpin yang mendampingi menjadi bagian penting dalam perkembangan dan kemajuan Yayasan Mercy Indonesia.

\section{Memberikan Penjelasan yang Menyejukkan}

Hasil penelitian dari hasil wawancara informan menunjukkan bahwa konsep kepemimpinan yang memberikan penjelasan yang menyejukkan dan menghibur telah ditunjukkan oleh pimpinan Yayasan Mercy Indonesia. Hal ini terlihat dari hasil wawancara yang berkaitan dengan upaya dan pendekatan yang dilakukan terhadap karyawan yang mengalami masalah dan pelanggaran. Dimana pimpinan mengedepankan nilai kasih dan kekeluargaan dalam memberikan nasehat, dorongan, bimbingan, maupun teguran pada karyawan yang mengalami masalah dan pelanggaran. 
Konsep kepemimpinan ini pun ditunjukkan oleh Rasul Paulus. Dalam teks 1 Korintus 4:18-21, Rasul Paulus memberikan penjelasan yang menghiburkan dan menyejukkan saat jemaat Korintus mengalami permasalahan dan perbantahan diantara jemaat. Konsep kepemimpinan ini menggambarkan gaya kepemimpinan yang demokratis. Sunindhia dan Widiyanti (2001) menegaskan bahwa kepemimpinan demokratis memperlakukan bawahan sebagai manusia, bukan alat. Artinya, pemimpin mesti dapat memperlakukan bawahan dengan baik, terutama dalam membangun komunikasi. Komunikasi yang ditunjukkan oleh pimpinan adalah komunikasi yang menyejukkan dan menghangatkan. Dengan komunikasi seperti ini, iklim dan suasana kerja menjadi nyaman dan kondusif. Konsep kepemimpinan seperti ini pun menjadi bagian dari konsep kepemimpinan yang ada di Yayasan Mercy Indonesia dalam perkembangan dan kemajuannya hingga saat ini.

Berdasarkan konsep kepemimpinan yang diutarakan di atas, menggambarkan bahwa kepemimpinan di Yayasan Mercy Indonesia sejalan dengan kepemimpinan Rasul Paulus. Dimana kepemimpinan Rasul Paulus terimplikasi dalam beberapa nilai kepemimpinan berikut ini, yaitu: pertama, pemimpin Kristen mesti memiliki konsep kepemimpinan yang mendidik dan membangun. Kedua, pemimpin Kristen mesti memiliki konsep kepemimpinan yang merangkul. Ketiga, pemimpin Kristen mesti memiliki konsep kepemimpinan yang dapat menjadi teladan. Keempat, pemimpin Kristen mesti memiliki konsep kepemimpinan yang dapat mendampingi bawahannya. Kelima, pemimpin Kristen mesti memiliki konsep kepemimpinan yang memiliki penjelasan dan komunikasi yang menyejukkan atau menghibur.

\section{Implikasi}

Penelitian ini berimplikasi pada kepemimpinan di yayasan-yayasan lembaga Kristen di Indonesia. Dimana diharapkan penelitian ini menjadi salah satu model kepemimpinan dalam mengembangkan dan mengelola yayasan. Dimana kepemimpinan Rasul Paulus diharapkan dapat diimplementasikan dalam kepemimpinan organisasi atau yayasan Kristen.

\section{Rekomendasi untuk Penelitian Lanjutan}

Penelitian ini mengkaji kepemimpinan Rasul Paulus berdasarkan teks 1 Korintus 4:1-21 sebagai model kepemimpinan di Yayasan Mercy Indonesia. Diharapkan untuk penelitian lanjutan dapat mengkaji konsep kepimpinan Rasul Paulus lainnya dari teksteks tulisan Paulus.

\section{Kesimpulan}

Hasil pembahasan di atas, menggambarkan konsep kepemimpinan demokratis yang ditunjukkan oleh pimpinan Yayasan Mercy Indonesia, Denpasar. Konsep kepemimpian tersebut didasarkan pada analisa teks 1 Korintus 4:1-21. Hasil penelitian menyimpulkan bahwa konsep kepemimpinan Rasul Paulus dalam perkembangan Yayasan Mercy Indonesia yaitu bahwa pemimpin Kristen mesti memiliki konsep 
kepemimpinan yang mendidik dan membangun, merangkul, dapat menjadi teladan, dapat mendampingi bawahannya, serta memiliki penjelasan dan komunikasi yang menyejukkan atau menghibur.

\section{Rujukan}

Arifin, S. (2012). Leadership: Ilmu dan Seni Kepemimpinan. Mitra Wacana Media.

Barclay, W. (2006). Pemahaman Alkitab Setiap Hari: Surat 1 dan 2 Korintus. BPK Gunung Mulia.

Handoko, T. H. (2001). Manajemen. BPFE.

Iksantoro. (2019). Potret Pemimpin Kristen Sebagai Sumber Daya Manusia Unggul Menurut Kitab Titus. Jurnal Teologi Berita Hidup, 2(1), 36-47. https://doi.org/10.38189/jtbh.v2i1.24

KBBI. (2009). Kamus Besar Bahasa Indonesia. Balai Pustaka.

Kouzes, J. M., \& Posner, B. Z. (2004). Leadership The Challenge: Tantangan Kepemimpinan. Erlangga.

Marxsen, W. (2009). Pengantar Perjanjian Baru Pendekatan Kritis Terhadap Masalahmasalahnya. BPK Gunung Mulia.

Maxwell, J. C. (2016). The Leadership Handbook: Pelajaran Penting Yang Dibutuhkan Semua Pemimpin. Gramedia.

Ningrat, S. H. (2003). Pengantar Ilmu Studi Administrasi dan Manajemen. Haji Masagung.

Ohodo, Y., \& Marini, R. R. (2021). Kualifikasi Pemimpin Jemaat Menurut 1 Timotius 3:1-7 bagi Gembala Sidang GPdI Wilayah Keerom Timur. KHARISMATA: Jurnal Teologi Pantekosta, 3(2), 117-131. https://doi.org/10.47167/kharis.v3i2.53

Oktavianus, P. (2003). Manajemen dan Kepemimpinan Menurut Wahyu Allah. Gandum Mas.

Satori, D. (2014). Metodologi Penelitian Kualitatif. Alfabeta.

Siagian, S. P. (2005). Teori dan Praktek Kepemimpinan. Rineka Cipta.

Stott, J. (2005). Menantang Kepemimpinan Kristiani. YKBK.

Sugiyono. (2016). Metode Penelitian Pendidikan: Pendekatan Kuantitatif, Kualitatif Dan $R \& D$. Alfabeta.

Sunindhia, Y. W., \& Widiyanti, N. (2001). Kepemimpinan Dalam Masyarakat Modern. Rineka Cipta.

Thoha, M. (2005). Perilaku Organisasi. Raja Grafindo Persada.

Tomatala, Y. (2005). Penatalayanan Gereja yang Efektif di Dunia Modern. Gandum Mas.

Tomatala, Y. (2008). Par-Excellence Leadership: Memimpin Seperti Yesus Kristus. Gandum Mas.

Westra, P. (2002). Ensiklopedi Administrasi. Haji Masagung.

Wiratno, P. (2019). Dokumen. 